\title{
EVALUASI KEBERHASILAN E-LEARNING DALAM PERSPEKTIF SISTEM INFORMASI (STUDI KASUS UNIVERSITAS TERBUKA)
}

\author{
EVALUATING E-LEARNING SUCCESS FROM INFORMATION SYSTEM PERSPECTIVE \\ (CASE STUDY OF INDONESIA OPEN UNIVERSITY)
}

\author{
ABD Rahmat ${ }^{* 1}$, Kudang Boro Seminar**), dan Arif Imam Suroso*) \\ *) Sekolah Bisnis, Institut University \\ Jl. Raya Pajajaran, Bogor 16151 \\ ${ }^{* *)}$ Departemen Teknik Mesin dan Biosistem, Fakultas Teknologi Pertanian, Institut University \\ Kampus IPB Darmaga PO BOX 220, Bogor 16002
}

\begin{abstract}
As a pioneer in e-learning implementation, UT is required to be able to provide an adequate information technology system continuously, particularly to reach an extensive area of Indonesia. The purpose of this study was to asses of e-learning implementation and to evaluate the factors that influenced e-learning at UT using the DeLone and McLean information system models. Data was collected using a structured questionnaire among two respondent categories, namely students and lecturers, using a convenience sampling method. The data from 300 respondents were then analyzed using the Partial Least Square method. The results indicate that information quality, system quality, service quality positive significantly influenced user satisfaction. Thus, information quality and service quality positive significantly influenced usage. The usage positive significantly influenced user experience, and the usage and user experience positive significantly influenced the net benefit. The conclusion was UT had implemented comprehensive e-learning with high success rates. This success was from the technical aspects of system quality and service quality. Effectively, this success also came from system usage, user satisfaction, and net results. The need for research Implications was explored for a suggestion for better management and utilization of e-learning strategies at the Indonesia Open University.
\end{abstract}

Keywords: DeLone dan McLean, e-learning, information system, PLS, Open University

\begin{abstract}
Abstrak: UT sebagai pionir perguruan tinggi yang menerapkan e-learning dituntut selalu dapat menyediakan sistem teknologi informasi yang memadai untuk menjangkau luasnya wilayah Indonesia. Tujuan dari penelitian ini adalah menilai kondisi penerapan e-learning dan menganalisis faktor-faktor yang memengaruhi keberhasilannya dengan menggunakan model sistem informasi DeLone dan McLean. Data dikumpulkan melalui kuesioner terstruktur dengan mahasiswa dan dosen menjadi responden penelitian. Pengumpulan sampel dilakukan dengan metode convenience sampling. Data dari 300 responden kemudian dianalisis dengan Partial Least Square. Hasilnya adalah kualitas informasi, kualitas sistem, dan kualitas layanan berpengaruh positif terhadap kepuasan pengguna. Kualitas layanan dan kualitas informasi berpengaruh positif terhadap penggunaan. Penggunaan berpengaruh positif terhadap kepuasan pengguna, dan penggunaan serta kepuasan pengguna berpengaruh positif terhadap hasil bersih. Kesimpulan yang diperoleh adalah UT telah mengimplementasikan e-learning secara menyeluruh dengan tingkat keberhasilan tinggi. Keberhasilan tersebut dilihat secara teknis yang tercermin dari kualitas sistem dan kualitas layanan. Secara efektifitas, keberhasilan tercermin dari penggunaan sistem, kepuasan pengguna, dan hasil bersih. Beberapa implikasi dari penelitian ini kemudian disajikan sebagai usulan bagi strategi pengelolaan dan pemanfaatan e-learning di UT yang lebih baik lagi.
\end{abstract}

Kata kunci: DeLone dan McLean, e-learning, PLS, sistem informasi, Universitas Terbuka

${ }^{1}$ Corresponding author:

Email: abd.rahmat@gmail.com 


\section{PENDAHULUAN}

E-learning merupakan salah satu aktivitas yang mendapatkan pengaruh paling signifikan dari perkembangan teknologi informasi saat ini. Di Indonesia, perguruan tinggi menjadi salah satu lembaga pendidikan yang sudah banyak mengembangkan sistem e-learning. Kementerian Riset Teknologi dan Pendidikan Tinggi telah menggalakkan program Cyber University dengan menerapkan sistem e-learning atau online learning melalui Peraturan Menteri No. 24 Tahun 2012 Tentang Penyelenggaraan Pendidikan Jarak Jauh oleh Perguruan Tinggi. Program ini diharapkan dapat menjadi salah satu solusi pembangunan pendidikan di Indonesia.

Universitas Terbuka (UT) merupakan perguruan tinggi pionir di Indonesia yang menerapkan sistem pendidikan jarak jauh dengan sedikit kelas (tatap muka). Pembelajaran dilakukan menggunakan media baik cetak (modul) maupun noncetak (internet, audio, dan video). UT merupakan prototipe ideal bagi perguruan tinggi di Indonesia dalam penerapan konsep e-learning. UT mengharuskan kegiatan belajar mengajar di kampus terdigitalisasi, tanpa batas waktu, dan dapat dilakukan di berbagai tempat. Sebagai pelopor e-learning dengan sumber daya dan sebaran layanan yang luas, UT dituntut untuk selalu dapat menyediakan sistem teknologi informasi yang memadai terlebih untuk menjangkau wilayah Indonesia yang sangat luas.

E-learning merupakan pembelajaran jarak jauh yang menggunakan teknologi komputer dan internet. Metode ini merupakan alternatif pengajaran yang dapat bertahan dalam jangka panjang dibandingkan dengan metode tatap muka tradisional dilihat dari sisi fleksibilitas waktu dan kepuasan siswa (Kratochvil, 2014). E-learning juga diarahkan untuk melakukan difusi dan koneksi konten serta kecenderungan konsep yang tidak lagi hanya menekankan computer-based semata (Aparicio et al. 2016). Dalam penerapan e-learning, faktor sistem informasi menjadi hal yang sangat krusial untuk diperhatikan dan dievaluasi (Chang et al. 2011).

Banyak negara berkembang tertarik untuk menerapkan e-learning pada sistem pendidikannya namun menghadapi banyak kendala. Kendala tersebut diantaranya adalah kekurangan skil, kompleksitas teknologi, kecocokan, biaya, infrastruktur yang kurang, isu keamanan dan privasi (Garg et al. 2015). Kurangnya pemahaman tentang manfaat penerapan IT, kurangnya kebijakan, dan resistensi perubahan juga kerap menjadi hambatan (Shraim dan Khlaif, 2010; Laferriere et al. 2013). Passey et al. (2016) menyatakan bahwa integrasi teknologi dalam pendidikan di negara berkembang memiliki kompleksitas tersendiri karena masalah politik, sosial, bahasa, budaya, dan ekonomi. Sridharan et al. (2010) merekomendasikan bahwa setiap penerapan sistem e-learning yang efektif perlu membahas teknologi, pedagogi, manajemen, dan individu. Bell dan Federman (2013) mengidentifikasi beberapa faktor yang memengaruhi adopsi e-learning yaitu keterlibatan dan interaksi. Berbagai aspek e-learning telah diteliti di negara-negara lain termasuk komponen berbasis pedagogi (Krämer dan Bente, 2010; Marshall, 2010), relasi siswa dan guru serta penerimaannya (Sarsa dan Soler, 2012), interaksi peserta dalam lingkungan online (Uukkivi, 2016) dan pengalaman siswa (Jung, 2011; Loh et al. 2016).

Indonesia sebagai salah satu negara berkembang dan UT sebagai pionir e-learning persis mengalami permasalahan seperti yang dipaparkan sebelumnya. Kondisi yang terjadi saat ini adalah kehandalan akses sistem di UT belum optimal dan sering terjadinya kendala dalam mengakses sistem pada kegiatan pembelajaran. Hal tersebut berakibat pada kurang maksimalnya penyerapan materi oleh peserta didik dan keberhasilan penerapan e-learning secara keseluruhan. Analisis untuk mengetahui faktor-faktor yang memengaruhi keberhasilan penerapan e-learning di Universitas Terbuka dirasakan penting, terutama dalam menyongsong era revolusi industri yang lebih fokus kepada penggunaan internet dan sistem informasi. Harapannya sistem pembelajaran ini dapat terus berkembang semakin luas dan lebih baik lagi. Salah satu model yang dikembangkan untuk mengevaluasi kesuksesan e-learning adalah model sistem informasi DeLone dan McLean (DeLone dan McLean, 2003).

Penelitian terkait evaluasi e-learning dengan menggunakan model sistem informasi DeLone dan McLean ini telah banyak dilakukan. Seperti dalam Holsapple dan Lee-Post (2006), Lee-Post (2009), dan Freeze et al. (2012), yang secara umum menyebutkan bahwa model DeLone dan McLean tersebut memiliki tingkat kecocokan dan kelengkapan tinggi untuk mengevaluasi e-learning dilihat dari aspek sistem informasi. Dalam konteks negara berkembang yang relevan dengan kondisi Indonesia, penelitian Raspopovic et al. (2014) di negara Serbia menjadi rujukan. Dengan menggunakan model sistem informasi 
DeLon dan McLean, penelitian ini mengevaluasi penerapan e-learning dan membandingkannya dengan metode pembelajaran tradisional. Hasilnya adalah penerapan e-learning telah mengalami kemajuan dan dapat dikategorikan telah sukses. Namun demikian, dilihat dari keluaran ataupun prestasi siswa, e-learning masih berada di bawah metode pengajaran tradisional. Di Indonesia, penelitian e-learning dalam ruang lingkup perguruan tinggi, belum banyak ditemukan. Penelitian dengan menggunakan model DeLone dan McLean lebih banyak diterapkan dalam pemerintahan dan perusahaan. Seperti pada Saputro et al. (2015) yang meneliti model DeLone dan McLean untuk mengukur keberhasilan penerapan e-government di Kota Pekalongan. Hasilnya adalah penerapan e-government oleh Pemerintah Kota Pekalongan telah berhasil membantu pelayanan kepada masyarakat dan mempermudah pekerjaan pegawai pemerintahan. Dalam ruang lingkup perusahaan, penelitian Yuliana (2016) pada perusahaan BUMN di Indonesia dapat menjadi rujukan. Dengan menggunakan metode SEM, diperoleh hasil bahwa kualitas sistem berpengaruh signifikan terhadap kepuasan pengguna, dan kepuasan pengguna berpengaruh signifikan terhadap dampak individual. Yang menarik adalah ternyata kualitas sistem dan kualitas informasi tidak mempengaruhi terhadap penggunaan. Begitu juga kualitas informasi juga tidak mempengaruhi terhadap kepuasan pengguna.

Apabila dibandingkan dengan beberapa penelitian sebelumnya, penelitian ini berada dalam ruang lingkup institusi pendidikan. Hal ini menjadi unsur keterbaruan yang peneliti-peneliti sebelumnya khususnya di Indonesia lebih banyak mendalami model sistem informasi dalam bidang pemerintahan dan perusahaan. Selain itu, penggunaan model DeLone dan McLean dengan sedikit modifikasi juga dilakukan karena menyesuaikan dengan karakteristik objek penelitian yang telah memanfaatkan penggunaan e-learning. Model modifikasi ini juga merupakan keterbaruan pada penelitian ini.

Penelitian ini bertujuan menilai kondisi penerapan e-learning di UT. Gambaran yang jelas fakta kondisi penerapan e-learning dapat membantu melihat keadaan sebenarnya di lapangan. Penelitian ini juga ingin menganalisis faktor-faktor yang memengaruhi keberhasilan implementasi sistem di UT dengan menggunakan model sistem informasi DeLone dan McLean. Identifikasi faktor berpengaruh akan sangat penting guna menentukan strategi prioritas perbaikan.

\section{METODE PENELITIAN}

E-learning di UT telah menjadi mandat dalam visi, misi, dan tujuan lembaga. Oleh karena itu evaluasi atas penerapannya menjadi penting dilakukan untuk mengetahui sejauh mana keberhasilannya. Model sistem informasi DeLone dan McLean digunakan untuk mengevaluasi kondisi pelaksanaan sekaligus menganalisis faktor yang memengaruhi keberhasilannya. Evaluasi dan analisis faktor tersebut kemudian dijadikan sebagai rekomendasi perbaikan sistem informasi e-learning di UT.

Penelitian dilakukan di UTUPBJJ Bogor dengan metode pengumpulan data menyerahkan daftar pertanyaan untuk diisi sendiri oleh responden berupa kuesioner (self-administered). Responden diberikan langsung kuesioner untuk diisi dan dikembalikan pada saat yang sama sehingga diperoleh rasio sukses pengumpulan kuesioner sebesar $100 \%$. Metode pengambilan sampel dilakukan secara tidak acak dengan convenience sampling terhadap para mahasiswa dan dosen terdaftar. Jumlah sampel digunakan sebanyak 300 orang. Pada setiap pertanyaan, responden mengisi atau memberikan penilaian atas persepsinya terhadap penerapan sistem e-learning di UT. Responden akan menuangkan penilaiannya tersebut pada angka yang dirasa sesuai dengan pengalaman yang dirasakan dengan kriteria skor $1=$ sangat rendah, $2=$ rendah, $3=$ sedang, $4=$ tinggi, dan 5 = sangat tinggi.

Analisis statistika deskriptif disajikan untuk menilai kondisi penerapan e-learning di UT berdasarkan variabel-variabel penelitian. Partial Least Square (PLS) kemudian digunakan untuk menganalisis model penelitian dengan menggunakan SmartPLS 3.0. Dalam analisis PLS, pengujian dengan prosedur dua tahap dilakukan sebagaimana Rodríguez-Entrena et al. (2018) dan Long et al. (2019) dengan menguji model pengukuran yang terdiri dari validitas dan reliabilitas, kemudian menguji model struktural untuk mengetahui signifikansi dari hipotesis penelitian.

Model yang digunakan dalampenelitian ini adalah model sistem informasi DeLon dan McLean sebagaimana Gambar 1. Model ini digunakan karena dapat mengukur keberhasilan penerapan e-learning dari sudut pandang sistem informasi secara keseluruhan. Pada penelitian ini, model DeLon dan McLean mengalami sedikit modifikasi yaitu menghilangkan variabel intention to use karena UT sudah menerapkan sistem e-learning. 
Oleh karena itu, variabel yang diteliti hanya dari sisi penggunaanya saja (use). Penelitian ini juga tidak melihat pengaruh balik dari net benefit terhadap use dan user satisfaction karena keterbatasan alat analisis yang digunakan.
Variabel yang digunakan dalam penelitian ini merujuk pada model sistem informasi DeLone dan McLean. Namun demikian, terdapat pengembangan beberapa indikator berdasarkan tinjauan literatur dan penelitian terdahulu. Pengembangan ini didasarkan pada kondisi yang telah terjadi di UT. Penjelasan mengenai variabel dan indikator dapat dilihat pada Tabel 1.

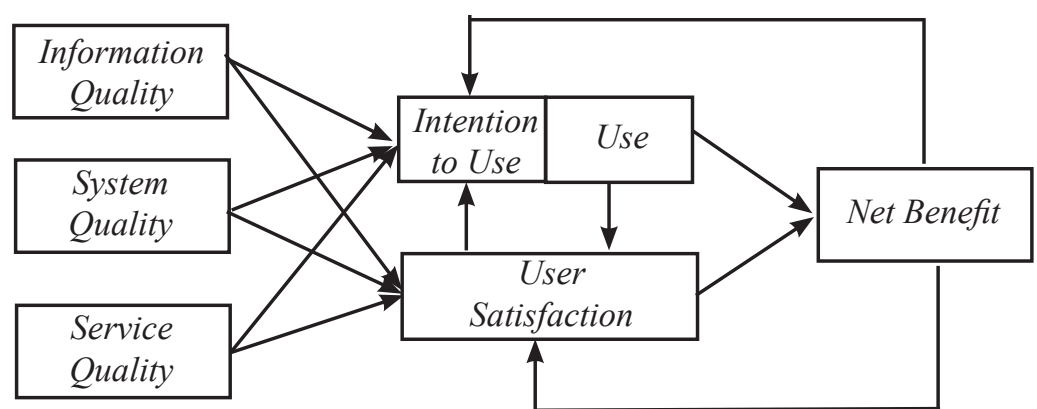

Gambar 1. Information system success model yang dibaharui (DeLone and McLean, 2003)

Tabel 1. Variabel-variabel dalam penelitian

\begin{tabular}{|c|c|c|c|}
\hline Variabel Laten & Mnemonik & Indikator & Rujukan \\
\hline \multirow{8}{*}{$\begin{array}{l}\text { Kualitas } \\
\text { informasi } \\
\text { (Eksogen) }\end{array}$} & IQ1 & Kelengkapan & DeLone dan McLean (2003) \\
\hline & IQ2 & Ditulis dengan jelas & Holsapple dan Lee-Post (2006) \\
\hline & IQ3 & Personalisasi & DeLone dan McLean (2003) \\
\hline & IQ4 & Keakuratan & $\begin{array}{l}\text { DeLone dan McLean (2003); Wannasiri et al. } \\
\text { (2012) }\end{array}$ \\
\hline & IQ5 & Tepat waktu & $\begin{array}{l}\text { DeLone dan McLean (2003); Wannasiri et al. } \\
\text { (2012) }\end{array}$ \\
\hline & IQ6 & Relevan & DeLone dan McLean (2003) \\
\hline & IQ7 & Mutakhir & Holsapple dan Lee-Post (2006) \\
\hline & IQ8 & Keamanan & $\begin{array}{l}\text { DeLone dan McLean (2003); Holsapple dan Lee- } \\
\text { Post (2006) }\end{array}$ \\
\hline \multirow{4}{*}{$\begin{array}{l}\text { Kualitas } \\
\text { sistem } \\
\text { (Eksogen) }\end{array}$} & SQ1 & Mudah digunakan & DeLone dan McLean (2003) \\
\hline & SQ2 & Kemampuan beradaptasi & DeLone dan McLean (2003) \\
\hline & SQ3 & Stabil & Holsapple dan Lee-Post (2006) \\
\hline & SQ4 & Cepat & DeLone dan McLean (2003) \\
\hline \multirow{3}{*}{$\begin{array}{l}\text { Kualitas } \\
\text { layanan } \\
\text { (Eksogen) }\end{array}$} & ScQ1 & Responsif & DeLone dan McLean (2003) \\
\hline & $\mathrm{ScQ} 2$ & Jaminan & DeLone dan McLean (2003) \\
\hline & ScQ3 & Perhatian & DeLone dan McLean (2003) \\
\hline \multirow{9}{*}{$\begin{array}{l}\text { Penggunaan } \\
\text { (Endogen) }\end{array}$} & Use1 & Slide Power Point & Holsapple dan Lee-Post (2006) \\
\hline & Use2 & Audio & Holsapple dan Lee-Post (2006) \\
\hline & Use3 & Naskah & Holsapple dan Lee-Post (2006) \\
\hline & Use4 & Papan diskusi & Holsapple dan Lee-Post (2006) \\
\hline & Use5 & Studi kasus & Holsapple dan Lee-Post (2006) \\
\hline & Use6 & Praktek masalah & Holsapple dan Lee-Post (2006) \\
\hline & Use7 & Tutorial Excel & Holsapple dan Lee-Post (2006) \\
\hline & Use8 & Tugas & Holsapple dan Lee-Post (2006) \\
\hline & Use9 & Ujian praktek & Holsapple dan Lee-Post (2006) \\
\hline
\end{tabular}


Tabel 1. Variabel-variabel dalam penelitian (Lanjutan)

\begin{tabular}{|c|c|c|c|}
\hline Variabel Laten & Mnemonik & Indikator & Rujukan \\
\hline \multirow{2}{*}{$\begin{array}{l}\text { Kepuasan } \\
\text { pengguna } \\
\text { (Endogen) }\end{array}$} & US1 & Kepuasan keseluruhan & Holsapple dan Lee-Post (2006) \\
\hline & US2 & $\begin{array}{l}\text { Pengalaman yang menyenang- } \\
\text { kan }\end{array}$ & Holsapple dan Lee-Post (2006) \\
\hline \multirow{6}{*}{$\begin{array}{l}\text { Hasil bersih yang } \\
\text { didapat (Endogen) }\end{array}$} & NB1 & Peningkatan pembelajaran & Holsapple dan Lee-Post (2006) \\
\hline & NB2 & Diberdayakan & Holsapple dan Lee-Post (2006) \\
\hline & NB3 & Hemat waktu & Holsapple dan Lee-Post (2006) \\
\hline & NB4 & Kesuksesan akademik & Holsapple dan Lee-Post (2006) \\
\hline & NB5 & Penghematan biaya & DeLone dan McLean (2003) \\
\hline & NB6 & Kesuksesan keseluruhan & Holsapple dan Lee-Post (2006) \\
\hline
\end{tabular}

Kualitas informasi merupakan ukuran kualitas keluaran dari sistem informasi. Kualitas sistem merupakan performa dari sistem yang merujuk pada seberapa baik kemampuan perangkat keras, perangkat lunak, kebijakan, prosedur dari sistem informasi dapat menyediakan informasi kebutuhan pengguna. Kualitas layanan sebagai sebuah perbandingan dari harapan pelanggan dengan persepsi dari layanan nyata yang mereka terima. Penggunaan terdiri dari dua bagian yaitu penggunaan keluaran dan penggunaan sistem yang berarti penggunaan informasi dan penggunaan dari sistem informasi itu sendiri. Kepuasan pemakai merupakan respon dan umpan balik yang dimunculkan pengguna setelah memakai sistem informasi. Hasil bersih yang didapat adalah keutungan yang dirasakan oleh individu dan juga organisasi setelah menerapkan sistem informasi (DeLone dan McLean, 2003). Dari keterlibatan beberapa variabel tersebut penulis merumuskan hipotesis dan model hubungan (Gambar 2) sebagai berikut:

H1 : Kualitas informasi (information system) tidak berpengaruh signifikan terhadap penggunaan sistem (use)

H1 : Kualitas informasi (information system) berpengaruh signifikan terhadap penggunaan sistem (use)

$\mathrm{Hb} \mathrm{H0} \quad$ : Kualitas informasi (information system) tidak berpengaruh signifikan terhadap kepuasan pengguna (user satisfaction)

H1 : Kualitas informasi (information system) berpengaruh signifikan terhadap kepuasan pengguna (user satisfaction)

$\mathrm{Hc} \mathrm{HO}$ : Kualitas sistem (system quality) tidak berpengaruh signifikan terhadap penggunaan (use)
H1 : Kualitas sistem (system quality) berpengaruh signifikan terhadap penggunaan (use)

Hd H0 : Kualitas sistem (system quality) tidak berpengaruh signifikan terhadap kepuasan pengguna (user satisfaction)

H1 : Kualitas sistem (system quality) berpengaruh signifikan terhadap kepuasan pengguna (user satisfaction)

He HO : Kualitas pelayanan (service quality) tidak berpengaruh signifikan terhadap penggunaan sistem (use)

H1 : Kualitas pelayanan (service quality) berpengaruh signifikan terhadap penggunaan sistem (use)

HfHO : Kualitas pelayanan (service quality) tidak berpengaruh signifi-kan terhadap kepuasan pengguna (user satisfaction)

H1 : Kualitas pelayanan (service quality) berpengaruh signifikan terhadap kepuasan pengguna (user satisfaction)

Hg H0 : Penggunaan sistem (use) tidak berpengaruh signifikan terhadap kepuasan pengguna (user satisfaction)

H1 : Penggunaan sistem (use) akan berpengaruh signifikan terhadap kepuasan pengguna (user satisfaction)

HhHO : Penggunaan sistem (use) akan tidak berpengaruh signifikan terhadap hasil bersih yang didapatkan (net benefit)

H1 : Penggunaan sistem (use) akan berpengaruh signifikan terhadap hasil bersih yang didapatkan (net benefit) 
Hi H0 : Kepuasan pengguna (user satisfaction) tidak berpengaruh signifikan terhadap hasil bersih yang didapatkan (net benefit)

H1 : Kepuasan pengguna (user satisfaction) berpengaruh signifikan terhadap hasil bersih yang didapatkan (net benefit)

\section{HASIL}

\section{Kondisi Penerapan E-learning}

Kondisi penerapan e-learning di UT dapat dilihat dari respon responden terhadap pertanyaan kuesioner yang diberikan. Dinilai dari sisi kualitas informasi, kualitas sistem, dan kualitas layanan sebagaimana pada Tabel 2, secara menyeluruh kualitas sistem dari penerapan e-learning di UT dinilai telah berkinerja baik. Bahkan dari sisi keterhandalannya dinilai oleh pengguna sebagai sangat baik (mean $>4$ ). Di antara indikator-indikator kualitas sistem seperti usabilitas, adaptabilitas, kecepatan, dan reliabilitas yang walaupun semuanya dinilai baik, akan tetapi dari sisi kecepatan dan reliabilitas relatif paling rendah. Padahal justru keduanya memiliki nilai factor loading yang lebih tinggi (Tabel 3). Hal ini menunjukkan bahwa perbaikan pada kualitas sistem apabila diperlukan diprioritaskan secara berurutan pada indikator reliabilitas dan kecepatan, setelah itu menyusul pada indikator usabilitas dan adaptabilitas.

Adapun dari sisi kualitas informasi, penerapan e-learning juga dinilai berkinerja baik khususnya pada indikator tepat waktu. Walaupun indikator ini dinilai baik namun relatif lebih rendah dari ketujuh indikator lainnya sebagai pembentuk kualitas informasi. Dari sisi nilai factor loading, indikator tepat waktu ternyata juga memiliki nilai yang paling rendah dalam memberikan kontribusi pada pembentukan kualitas informasi. Sedangkan indikator keakurasian dinilai paling dominan memberikan kontribusi pada pembentukan kualitas informasi. Selanjutnya, dari sisi kualitas layanan, para responden pengguna menilai bahwa baik dari sisi indikator responsifnya, jaminannya, dan empatinya serta secara keseluruhan kinerja layanan dari sistem e-learning di UT semuanya dinilai baik.

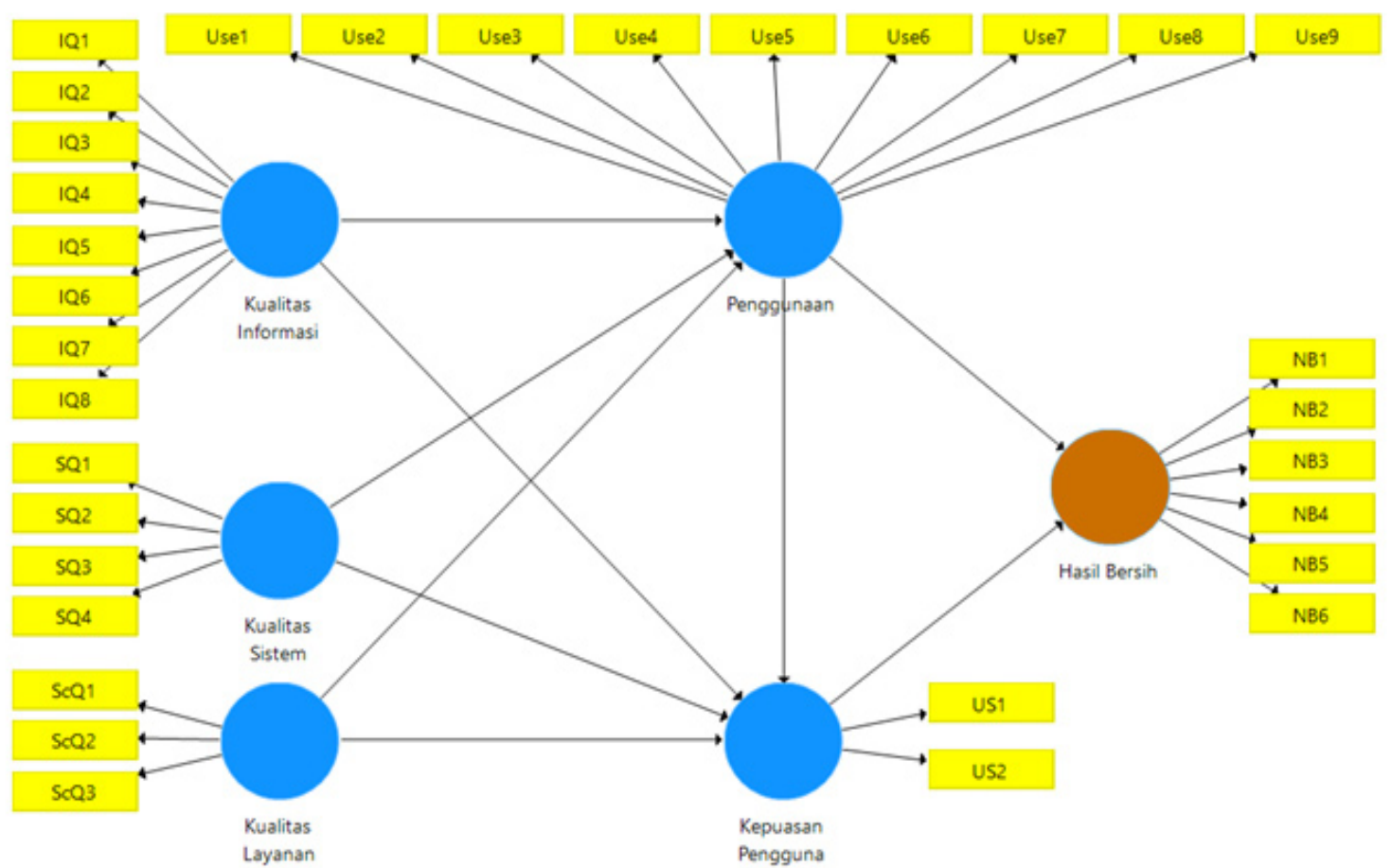

Gambar 2. Hubungan antar variabel 
Tabel 2. Kondisi penerapan e-learning: kualitas sistem, informasi, dan layanan

\begin{tabular}{|c|c|c|c|}
\hline Konstruk & Indikator & Mnemonik & Mean \\
\hline Kualitas informasi & Kelengkapan (completeness) & IQ1 & 4,20 \\
\hline \multirow[t]{8}{*}{ (information quality) } & Ditulis dengan jelas (clearly written) & IQ2 & 4,19 \\
\hline & Personalisasi (personalization) & IQ3 & 4,24 \\
\hline & Keakuratan (accuracy) & IQ4 & 4,29 \\
\hline & Tepat waktu (timelines) & IQ5 & 4,00 \\
\hline & Relevan (relevance) & IQ6 & 4,20 \\
\hline & Mutakhir (up-to-date) & IQ7 & 4,16 \\
\hline & Keamanan (security) & IQ8 & 4,17 \\
\hline & & Mean & 4,18 \\
\hline Kualitas system & Mudah digunakan (usability) & SQ1 & 4,18 \\
\hline \multirow[t]{4}{*}{ (systems quality) } & Kemampuan beradaptasi (adaptability) & SQ2 & 4,27 \\
\hline & Stabil (reliability) & SQ3 & 3,78 \\
\hline & Cepat (response time) & SQ4 & 3,95 \\
\hline & & Mean & 4,04 \\
\hline Kualitas layanan & Responsif (responsiveness) & ScQ1 & 4,05 \\
\hline \multirow[t]{3}{*}{ (service quality) } & Jaminan (assurance) & ScQ2 & 4,17 \\
\hline & Perhatian (empathy) & $\mathrm{ScQ3}$ & 4,03 \\
\hline & & Mean & 4,08 \\
\hline
\end{tabular}

Tabel 3. Hasil validitas konvergen pada model

\begin{tabular}{|c|c|c|c|c|c|c|c|c|c|}
\hline $\begin{array}{l}\text { Variabel } \\
\text { Laten } \\
\end{array}$ & Mnemonik & $\begin{array}{l}\text { Factor } \\
\text { loading }\end{array}$ & $\begin{array}{l}\text { Composite } \\
\text { reliability }^{a}\end{array}$ & $\mathrm{AVE}^{\mathrm{b}}$ & $\begin{array}{l}\text { Variabel } \\
\text { Laten } \\
\end{array}$ & Mnemonik & $\begin{array}{l}\text { Factor } \\
\text { loading }\end{array}$ & $\begin{array}{l}\text { Composite } \\
\text { reliability }^{a}\end{array}$ & $\mathrm{AVE}^{\mathrm{b}}$ \\
\hline \multirow{8}{*}{$\begin{array}{l}\text { Kualitas } \\
\text { informasi } \\
\text { (Eksogen) }\end{array}$} & IQ1 & 0,808 & \multirow[t]{8}{*}{0,934} & \multirow[t]{8}{*}{0,638} & \multirow{8}{*}{$\begin{array}{l}\text { Penggunaan } \\
\text { (Endogen) }\end{array}$} & Use1 & 0,800 & \multirow[t]{9}{*}{0,946} & \multirow[t]{8}{*}{0,661} \\
\hline & IQ2 & 0,782 & & & & Use2 & 0,821 & & \\
\hline & IQ3 & 0,814 & & & & Use3 & 0,805 & & \\
\hline & IQ4 & 0,828 & & & & Use4 & 0,803 & & \\
\hline & IQ5 & 0,750 & & & & Use5 & 0,852 & & \\
\hline & IQ6 & 0,824 & & & & Use6 & 0,809 & & \\
\hline & IQ7 & 0,809 & & & & Use7 & 0,806 & & \\
\hline & IQ8 & 0,771 & & & & Use8 & 0,824 & & \\
\hline \multirow{4}{*}{$\begin{array}{l}\text { Kualitas } \\
\text { sistem } \\
\text { (Eksogen) }\end{array}$} & SQ1 & 0,775 & \multirow[t]{4}{*}{0,874} & \multirow[t]{4}{*}{0,634} & & Use9 & 0,797 & & \\
\hline & SQ2 & 0,765 & & & \multirow{3}{*}{$\begin{array}{l}\text { Kepuasan } \\
\text { pengguna } \\
\text { (Endogen) }\end{array}$} & US1 & 0,929 & \multirow[t]{3}{*}{0,927} & \multirow[t]{3}{*}{0,864} \\
\hline & SQ3 & 0,815 & & & & US2 & 0,930 & & \\
\hline & SQ4 & 0,828 & & & & & & & \\
\hline \multirow{4}{*}{$\begin{array}{l}\text { Kualitas } \\
\text { layanan } \\
\text { (Eksogen) }\end{array}$} & ScQ1 & 0,894 & \multirow[t]{3}{*}{0,917} & \multirow[t]{4}{*}{0,786} & \multirow{6}{*}{$\begin{array}{l}\text { Hasil } \\
\text { bersih yang } \\
\text { didapat } \\
\text { (Endogen) }\end{array}$} & NB1 & 0,835 & \multirow[t]{6}{*}{0,935} & \multirow[t]{6}{*}{0,704} \\
\hline & $\mathrm{ScQ} 2$ & 0,892 & & & & NB2 & 0,864 & & \\
\hline & $\mathrm{ScQ3}$ & 0,873 & & & & NB3 & 0,833 & & \\
\hline & & & & & & NB4 & 0,850 & & \\
\hline \multirow{2}{*}{\multicolumn{5}{|c|}{$\begin{array}{l}\text { a Composite reliability }=(\text { kuadrat dari penjumlahan factor } \\
\text { loading) } /\{\text { (kuadrat dari penjumlahan factor loading })+ \\
\text { (kuadrat dari penjumlahan galat varians })\}\end{array}$}} & & NB5 & 0,813 & & \\
\hline & & & & & & NB6 & 0,840 & & \\
\hline
\end{tabular}

${ }^{\mathrm{b}} \mathrm{AVE}=$ (penjumlahan akar factor loading $) /\{($ penjumlahan akar factor loading) + (penjumlahan galat varians) $\}$ 
Selanjutnya evaluasi dinilai dari sisi penggunaan, kepuasan pengguna, dan hasil bersih sebagaimana Tabel 4. Kondisi peggunaan sistem e-learning di UT secara menyeluruh dinilai baik. Hanya indikator penggunaan studi kasus dan indikator ujian praktek yang walaupun juga dinilai baik, tetapi relatif lebih rendah dibandingkan dengan enam indikator lainnya. Apabila hendak diurutkan relatif dari tingkat kebaikan penggunaannya adalah dari sisi penggunaan tugas, penggunaan praktik masalah, penggunaan audio, slide PowerPoint, naskah, papan diskusi, tutorial, studi kasus, dan penggunaan ujian praktek. Dari sisi kontributornya terhadap penggunaan sistem indikator penggunaan studi kasus merupakan penyumbang tertinggi, mengingat nilai factor loading yang paling tinggi kemudian disusul oleh indikator tugas. Ketujuh indikator lainnya relatif memiliki kontribusi yang sama dalam pembentukan konstruk penggunaan sistem.

Kepuasan pengguna dari sistem ini juga dinilai tinggi. Hal tersebut dapat dilihat dari sisi indikator pengalaman yang menyenangkan dalam menggunakan sistem e-learning. Pengguna memberikan penilaian kepuasan yang relatif lebih tinggi dibandingkan indikator lainnya yaitu kepuasan dalam segala aspek penggunaan sistem.
Secara menyeluruh implementasi dari e-learning di Universitas Terbuka mempunyai tingkat keberhasilan yang tinggi. Implementasi e-learning ini berturut-turut secara relatif dinilai telah memperoleh kesuksesan yang tinggi khususnya dilihat dari sisi indikator penghematan biaya, penghematan waktu, dan kesuksesan akademik. Hal lainnya seperti munculnya perasaan diberdayakan, anggapan bahwa sistem secara menyeluruh sukses, dan adanya peningkatan dalam pembelajaran, juga menjadi indikator yang dinilai memiliki kesuksesan tinggi.

\section{Faktor-faktor yang Memengaruhi Keberhasilan Penerapan E-learning}

Setelah melihat secara deskriptif respon responden terhadap penerapan e-learning di UT, langkah selanjutnya adalah menganalisis model dengan PLS. Langkah pertama yang dilakukan adalah mengevaluasi model pengukuran yang dihasilkan. Evaluasi model struktural ini untuk menggambarkan seberapa baik indikator-indikator merefleksikan variabel konstruknya. Evaluasi model pengukuran dapat dilihat dari dua parameter utama yaitu validitas konvergen dan validitas diskriminan.

Tabel 4. Kondisi penggunaan, kepuasan pengguna dan hasil bersih (net benefit)

\begin{tabular}{|c|c|c|c|}
\hline Variabel Laten & Indikator & Mnemonik & Mean \\
\hline \multirow[t]{10}{*}{ Penggunaan } & Slide powerpoint (powerpoint slides) & Use1 & 4,15 \\
\hline & Audio & Use2 & 4,16 \\
\hline & Naskah (script) & Use3 & 4,14 \\
\hline & Papan diskusi (discussion board) & Use4 & 4,14 \\
\hline & Studi kasus (case studies) & Use5 & 4,09 \\
\hline & Praktik masalah (practice problems) & Use6 & 4,17 \\
\hline & Tutorial excel (excel tutorials) & Use7 & 4,09 \\
\hline & Tugas (assignment) & Use8 & 4,21 \\
\hline & Ujian praktek (practice exam) & Use9 & 4,09 \\
\hline & & Mean & 4,14 \\
\hline \multirow{3}{*}{$\begin{array}{l}\text { Kepuasan pengguna } \\
\text { (user satisfaction) }\end{array}$} & Kepuasan keseluruhan (overall satisfaction) & US1 & 4,17 \\
\hline & Pengalaman yang menyenangkan (enjoyable experience) & US2 & 4,24 \\
\hline & & Mean & 4,20 \\
\hline \multirow{7}{*}{$\begin{array}{l}\text { Hasil bersih yang didapat } \\
\text { (net benefits) }\end{array}$} & Peningkatan pembelajaran (enhanced learning) & NB1 & 4,16 \\
\hline & Diberdayakan (empowered) & NB2 & 4,17 \\
\hline & Hemat waktu (time savings) & NB3 & 4,33 \\
\hline & Kesuksesan akademik (academic success) & NB4 & 4,29 \\
\hline & Penghematan biaya (cost efficiency) & NB5 & 4,39 \\
\hline & Kesuksesan keseluruhan (overall success) & NB6 & 4,17 \\
\hline & & Mean & 4,27 \\
\hline
\end{tabular}


Dalam menguji validitas konvergen, terdapat setidaknya tiga parameter yang diuji, yaitu factor loading, reliabilitas komposit, dan Average Variance Extracted (Hair et al. 2010). Menurut Hair et al. (2010) standar nilai factor loading untuk seluruh indikator minimal sebesar 0,6 , standar nilai reliabilitas komposit minimal sebesar 0,7 , dan standar nilai AVE minimal sebesar 0,5. Tabel 3 menyajikan hasil validitas konvergen dimaksud.

Nilai factor loading telah memenuhi syarat lebih dari 0,6 . Nilai reliabilitas komposit untuk setiap variabel konstruk berada dalam rentang 0,874 dan 0,946 yang melebihi batas nilai yang ditentukan. Nilai AVE untuk setiap variabel konstruk berada dalam rentang 0,634 dan 0,864 yang juga melebihi batas nilai yang ditentukan. Setelah dilakukan evaluasi validitas konvergen, selanjutnya dilakukan evaluasi pengukuran validitas diskrimian dengan melihat nilai cross loading untuk setiap variabel.

Tahapan ini bertujuan membuktikan akurasi, konsistensi, dan ketepatan instrumen dalam mengukur konstruk. Analisis ini dapat diketahui dengan nilai cross loading yang harus lebih besar dari 0,60. Tabel 5 menunjukkan hasil cross loading yang menunjukkan seluruh nilai indikator pada setiap variabel konstruk menunjukkan parameter cross loading yang lebih besar dari 0,60. Dengan melihat parameter yang diperlukan pada evaluasi model pengukuran sebagaimana Tabel 4 dan 5, dapat disimpulkan secara umum model sudah cukup memenuhi syarat validitas konvergen dan validitas diskriminan.

Langkah kedua yang dilakukan adalah mengevaluasi model struktural, yaitu model hubungan antara variabel konstruk. Pada tahapan ini parameter yang dilihat adalah reliabilitas Cronbach, R-square, dan koefisien jalur. Analisis reliabilitas dilakukan untuk mengetahui seberapa konsisten sebuah instrumen mengukur konsep yang diukur. Nilai yang dianjurkan adalah lebih besar dari 0,6. Tabel 6 menunjukkan bahwa seluruh nilai alpha lebih besar dari 0,6, sehingga dapat disimpulkan bahwa pengukuran model reliabel.

Ringkasan model struktural dapat dilihat pada Tabel 7. R-square digunakan untuk melihat sejauh mana variabel eksogen mampu menerangkan keragaman variabel terikatnya. Selanjutnya dilihat nilai R-square dan analisis jalur yang mengindikasikan seberapa baik data mendukung hipotesis yang diajukan bila $\mathrm{p} \leq 0,01$ atau secara statistik dinyatakan signifikan.
Secara total, kualitas informasi, kualitas sistem, kualitas layanan, dan penggunaan berpengaruh signifikan terhadap kepuasan pengguna. Kualitas informasi dan kualitas layanan berpengaruh signifikan terhadap penggunaan. Penggunaan dan kepuasan pengguna berpengaruh signifikan terhadap hasil bersih yang didapat. Semua hubungan yang signifikan memiliki tanda koefisien jalur yang positif. Ini berarti hubungan antara variabel-variabel yang ada searah. Hubungan dan tanda koefisien dapat dilihat pada Gambar 3. Dari penelitian ini diperoleh juga hasil bahwa semua hipotesis yang ada signifikan positif kecuali pada pengaruh kualitas sistem terhadap penggunaan karena $\mathrm{p}<0,05$.

Variabel kualitas informasi, kualitas sistem, kualitas layanan, penggunaan, dan kepuasan pengguna menjelaskan $77,6 \%$ variasi dari hasil bersih yang didapat. Variabel kualitas informasi, kualitas sistem, dan kualitas layanan menjelaskan $74,6 \%$ variasi dari penggunaan. Variabel kualitas informasi, kualitas sistem, kualitas layanan, dan penggunaan menjelaskan $69,0 \%$ variasi dari kepuasan pengguna. Dari Gambar 3 , apabila dilihat secara direct effect terhadap hasil bersih yang didapat, faktor Penggunaan memiliki nilai koefisien terbesar yaitu 0,469 .

\section{Implikasi Manajerial}

Dari hasil penelitian ini disarankan bagi pengelola UT untuk setidaknya mempertahankan atau berupaya meningkatkan pencapaian penerapan e-learning yang dinilai sudah tinggi, baik keberhasilannya di level teknis, level semantik, maupun level efektifitasnya. Pada keberhasilan level teknis dapat dilakukan dengan memperbaiki kondisi dari indikator-indikator pembentuk kualitas sistem dan kualitas layanan. Upaya perbaikan pada kualitas sistem prioritas utamanya berturut-turut pada indikator reliabilitas dan kecepatan, setelah itu menyusul pada indikator usabilitas dan adaptabilitas. Sedangkan dari sisi kualitas layanan perbaikan dapat dilakukan secara berurutan dengan mendorong kinerja dalam hal layanan yang responsif, jaminan dan empati dalam memberikan layanan. Dari sisi level semantik upaya peningkatan keberhasilannya dapat dilakukan melalui perbaikan secara berurutan pada sisi keakurasian informasi, relevansi informasi, personalisasi informasi, kemutakhiran informasi, kejelasan penulisan informasi, kemutakhiran, dan keakurasian. 
Dari sisi keberhasilan efektifitas penerapan e-learning dipengaruhi oleh penggunaan sistem, pemanfaatan sistem dan hasil bersih penerapan sistem. Upaya peningkatan hasil bersih penerapan e-learning dapat dilakukan dengan upaya peningkatan intensitas penggunaan dari sistem dan juga memperhatikan faktorfaktor yang membentuk kepuasan pengguna dan faktorfaktor yang memengaruhi kepuasan pengguna. Dari sisi penggunaan sistem hal yang dapat diperhatikan oleh pengelola adalah peningkatan penggunaan studi kasus. Hal ini dapat dicermati dari kondisi penggunaan studi kasus saat ini dan nilai factor loading dari indikator tersebut. Adapun dari sisi kepuasan pengguna upaya perbaikan dapat dilakukan dengan mendorong level dari kualitas layanan khususnya bagaimana meningkatkan responsiveness dari pengelola sistem.

\section{KESIMPULAN DAN SARAN}

\section{Kesimpulan}

Secara menyeluruh implementasi e-learning di UT mempunyai tingkat keberhasilan yang tinggi. Level keberhasilan tinggi dijumpai pada level teknis yang tercermin dari tingginya kualitas sistem dan kualitas layanan. Tingginya kualitas pada level semantik tercermin dari informasi. Tingginya kualitas pada level efektifitas sistem tercermin dari tingginya penggunaan sistem kepuasan pengguna terhadap sistem dan hasil bersih dari sistem yang ada.

Keberhasilan teknis yang tercermin dari kualitas sistem dan kualitas layanan e-learning di UT dipengaruhi oleh indikator-indikator yang membentuk kedua variabel tersebut. Sedangkan keberhasilan semantik yang tercermin dari kualitas informasi e-learning di UT dipengaruhi oleh indikator-indikator yang membentuk kualitas informasi. Adapun dari sisi keberhasilan efektifitas sistem e-learning dapat dilihat dari keberhasilan dari sisi penggunaan sistem, kepuasan pengguna sistem dan hasil bersih dari sistem. Keberhasilan dari penggunaan sistem dipengaruhi oleh keberhasilan dari kualitas informasi dan kualitas layanan. Adapun keberhasilan kepuasan pengguna dipengaruhi oleh keberhasilan kualitas sistem, kualitas layanan, dan kualitas informasi serta dari penggunaan sistem.

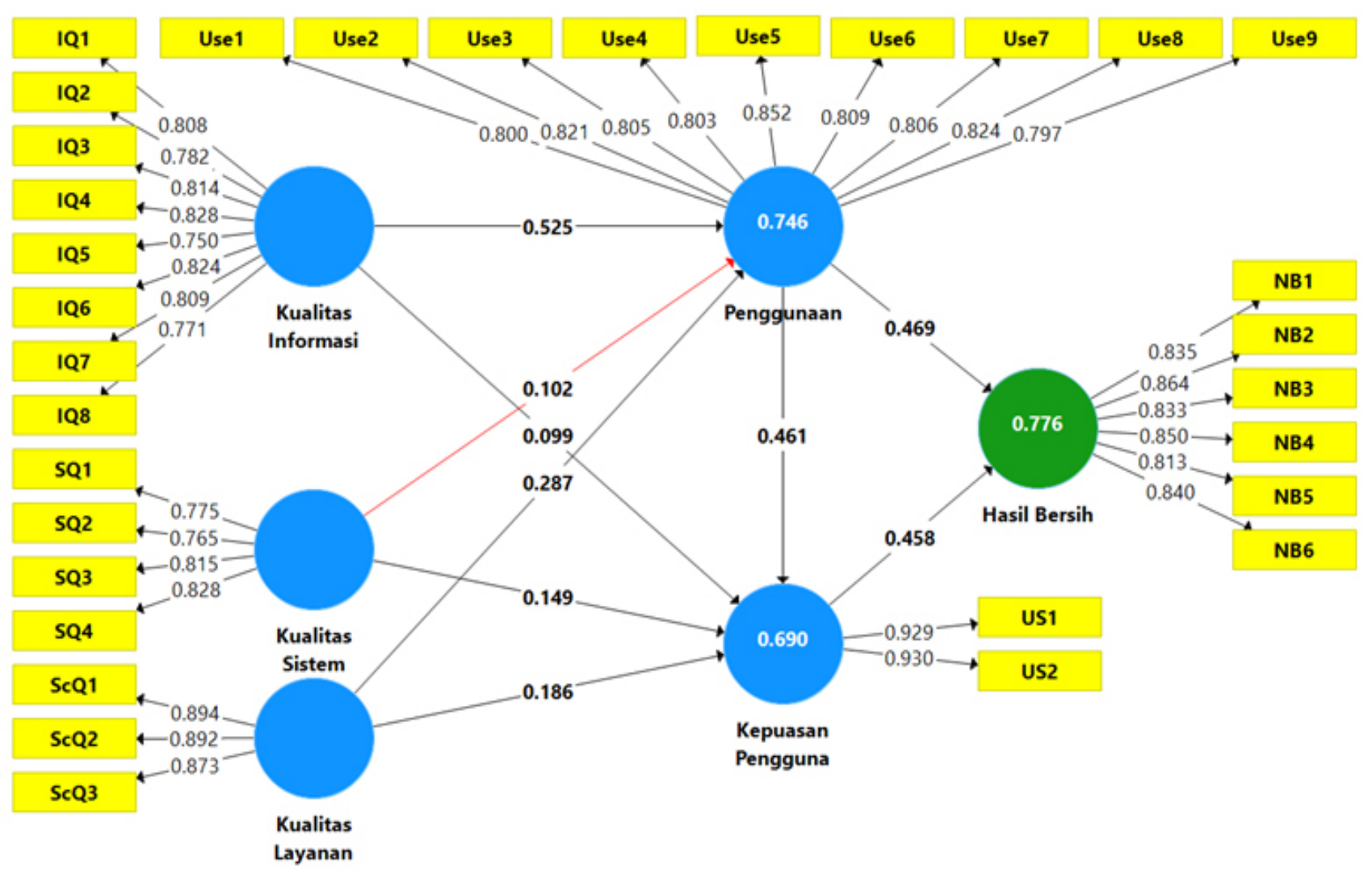

Gambar 3. Hasil model struktural 
Selanjutnya keberhasilan hasil bersih dari sistem dipengaruhi oleh indikator pembentuknya yaitu penghematan biaya, penghematan waktu, keberhasilan akademik, munculnya perasaan diberdayakan, anggapan bahwa sistem secara menyeluruh sukses dan adanya peningkatan dalam pembelajaran. Selain itu hasil bersih dari penerapan e-learning di UT berturutturut dipengaruhi oleh penggunaan sistem e-learning dan kepuasan pengguna dari sistem e-learning di perguruan tinggi. Secara tidak langsung melalui jalur penggunaan sistem, besaran tinggi pengaruhnya terhadap keberhasilan hasil bersih penerapan e-learning berturut-turut adalah kualitas informasi dan kualitas layanannya. Sedangkan secara tidak langsung melalui jalur kepuasan pengguna, besaran tinggi pengaruhnya terhadap keberhasilan hasil bersih penerapan e-learning berturut-turut adalah kualitas layanan, kualitas sistem, dan kualitas informasinya.

\section{Saran}

Penggunaan sistem pembelajaran e-learning ke depan dapat dipastikan semakin meningkat seiring tumbuh pesatnya bidang informasi dan teknologi. Perluasan objek kajian yang tidak hanya dibatasi pada Universitas Terbuka saja namun juga meliputi berbagai perguruan tinggi yang telah menyelenggarakan e-learning. Terlebih penyelenggaraan e-learning tersebut dilakukan di perguruan tinggi berstatuskan Perguruan Tinggi Negara berbadan hukum dapat menjadi penelitian lanjutan. Penggunaan model evaluasi sistem informasi lain, seperti misalnya service quality (servqual) menarik untuk dikaji lebih dalam. Penggunaan model DeLone dan McLean tanpa modifikasi juga bisa diterapkan dalam mengevaluasi sistem informasi Lembaga pada tahapan inisiasi.

\section{DAFTAR PUSTAKA}

Aparicio M, Bacao F, Oliveira T. 2016. An e-learning theoretical framework. Educational Technology and Society 19(1): 292-307.

BellBS,Federman JE.2013.E-learning inpostsecondary education. The Future of Children 23(1): 165185. https://doi.org/10.1353/foc.2013.0007.

Chang H, Liu C, Hwang H. 2011. Exploring nursing e-learning systems success based on information system success model. Computers, Informatics, Nursing:CIN 29(12):741-747. https://doi. org/10.1097/NCN.0b013e31821a1651.
DeLone WH, McLean ER. 2003. The DeLone and McLean model of information systems success: a ten-year update. Journal Management Information System 19(4): 9-30. https://doi.org /10.1080/07421222.2003.11045748.

Freeze RD, Alshare KA, Lane PL, Wen HJ. 2012. Is success model in e-learning context based on students' perceptions. Journal of Information System Education 21(2):173-184.

Garg A, Shukla B, Kendall G. 2015. Barriers to implementation of IT in educational institutions. The International Journal of Information and Learning Technology 32(2):94-108. https://doi. org/10.1108/IJILT-11-2014-0026.

Hair JF, Black WC, Babin BJ, Anderson RE. 2010. Multivariate Data Analysis. New Jersey: Prentice-Hall.

Holsapple CW, Lee-Post A. 2006. Defining, assessing, and promoting e-learning success: an information systems perspective. Decision Sciences Journal of Innovative Education 4(1):67-85.https://doi. org/10.1111/j.1540-4609.2006.00102.x.

Jung I. 2011. The dimensions of e-learning quality: From the learner's perspective. Educational Technology, Research and Development 59(4):445-464. https://doi.org/10.1007/s11423010-9171-4.

Krämer NC, Bente G. 2010. Personalizing e-learning. the social effects of pedagogical agents. Educational Psychology Review 22(1):71-87. https://doi.org/10.1007/s10648-010-9123-x.

Kratochvil J. 2014. Efficiency of e-learning in an information literacy course for medical students at the masaryk university. The Electronic Library 32(3):322-340.https://doi.org/10.1108/EL-072012-0087.

Laferriere T, Hame C, Searson M. 2013. Barriers to successful implementation of technology integration in educational settings: a case study. Journal of Computer Assisted Learning 29(5):463-473.https://doi.org/10.1111/ jcal.12034.

Lee-Post A. 2009. E-learning success model: an information systems perspective. Electronic Journal of e-learning 7(1):61-70.

Loh C, Wong DH, Quazi A, Kingshott RP. 2016. Reexamining students' perception of e-learning: An australian perspective. The International Journal of Educational Management 30(1):129-139. https://doi.org/10.1108/IJEM-08-2014-0114. 
Long Z, Wang Y, Liu X, Yao L. 2019. Two-step partial least square regression classifiers in brain-state decoding using functional magnetic resonance imaging. PloS One 14(4).https://doi.org/10.1371/ journal.pone.0214937.

Marshall S. 2010. A quality framework for continuous improvement of e-learning: The e-learning maturity model. Journal of Distance Education 24(1):143-165.https://doi.org/10.1108/ dlo.2010.08124aad.001.

Passey D, Laferrière T, Ahmad MYA, Bhowmik M, Gross D, Price J, Resta P, Shonfeld M. 2016. Educational digital technologies in developing countries challenge third party providers. Educational Technology \& Society 19 (3):121133.

Raspopovic M, Jankulovic A, Runic J, Lucic V. 2014. Success factors for e-learning in a developing country: a case study of Serbia. International Review of Research in Open and Distance Learning 15(3):1-23.https://doi.org/10.19173/ irrodl.v15i3.1586.

Rodríguez-Entrena M, Schuberth F, Gelhard C. 2018. Assessing statistical differences between parameters estimates in partial least squares path modeling. Quality and Quantity 52(1):57-69. https://doi.org/10.1007/s11135-016-0400-8.
Saputro PH, Budiyanto AD, Santoso AJ. 2015. Model DeLone and McLean untuk mengukur kesuksesan e-government Kota Pekalongan. Scientific Journal of Informatics 2(1):1-8.https:// doi.org/10.15294/sji.v2i1.4523.

Sarsa J, Soler R. 2012. E-learning quality: Relations and perceptions. International Journal of Information and Communication Technology Education 8(2):46-60. https://doi.org/10.4018/ jicte. 2012040104 .

Shraim K, Khlaif Z. 2010. An e-learning approach to secondary education in Palestine: opportunities and challenges. Information Technology for Development 16(3):159-173. https://doi.org/10. 1080/02681102.2010.501782.

Sridharan B, Deng H, Corbitt B. 2010. Critical success factors in e-learning ecosystems: a qualitative study. Journal of Systems and Information Technology 12(4):263-288. https://doi. org/10.1108/13287261011095798.

Uukkivi A. 2016. Personal factors supporting intercultural communication in e-learning of information sciences. Library Review 65(1):20 32.https://doi.org/10.1108/LR-01-2015-0002.

Yuliana K. 2016. Model kesuksesan sistem informasi DeLone dan McLean untuk evaluasi sistem informasi pos pada PT Pos Indonesia (Persero) divisi regional VI Semarang. INFOKAM 2(12):13-23. 